\title{
A world of change in the editorial office
}

\author{
Diana Epstein ${ }^{1}$
}

Received: 31 March 2016/Accepted: 31 March 2016/Published online: 19 April 2016

(C) Springer-Verlag Berlin Heidelberg 2016

It is hard to believe that 20 years have passed so quickly. I have been very lucky in having worked with the most professional of people, editors and publishers alike.

I took the job for 6 months initially and I am still here 20 years later. I began working at the University Eye Clinic in Cologne with the late Prof. Klaus Heiman, my first editor, then with Prof. Krieglstein for 3 years; followed by Prof. Kirchhof and since the past 5 years with Profs. Joussen and Wong. It is hard to believe that during 20 years I have worked with just five editors. I do believe that having a stable editorial office brings stability to the journal and contributes to its success.

The greatest and most major change during this time has been technology and the development of the Internet. When I began, there was a very old and forlorn looking computer, metal cabinets with paperwork, and files. An old desk and phone. To make decisions, Prof. Heiman would come into the office and have a cup of tea, we would discuss the papers, politics, opera, music, and put the world to right! When Prof. Krieglstein took over, I would go from the 3rd floor where the office was based to the ground floor. Meetings were scheduled for the mid-morning break and a cup of tea! Suffice to say on many occasions the lift was out of order and I had to make multiple trips to the ground floor in order to discuss the papers.

When Prof. Kirchhof took over, the on-line submission process had evolved. This resulted in the publishers investing in a computer system and ensured that I would not spend hours waiting at the post office to send papers to reviewers.

Twitter:@diepbiomed

Diana Epstein

graefes_archive@di-ep.com; http://www.di-ep.com

1 Di-Ep Biomedical Editorial Services Ltd, "Millworks" 28 Field Road, Glasgow G76 8SE, Scotland, UK
From a yearly submission of 280 papers to the current 1500 annual submissions, the success of the journal can be measured.

Twenty years ago "tweet" was the noise a bird made, smartphones were unheard of, and tablets were medication. You could only go surfing at the beach! A lot has changed since then. The editorial office today has a Twitter account and papers published in our journal discuss smartphones [1] and tablets [2]. Topics which would have been laughed at and considered science fiction 20 years ago. Downloading an online article was unheard of, but we now have our own online website for articles: http://www.springer.com/medicine/ ophthalmology/journal/417 All articles with Open Access are freely available while some other articles are freely available for 60 days.

The editorial office has had to deal with difficult issues during this time. Authorship being one which resulted in an editorial being published and again a second editorial $[3,4]$. Now, in addition to the Authorship Form, which all named authors need to sign, we introduced in January this year an automated letter sent by e-mail to all named authors advising that their names appear on the submitted paper as co-authors.

Guidelines have also developed during the years, COPE (Committee on Publication Ethics) of which SpringerNature is a member. The guidelines are in essence flowcharts and are freely available on the Internet. The guidelines cover topics such as authorship, redundant publications, data splicing, retractions, and more [5].

The Consort guidelines and trial reporting have developed [6]. The statement in regards to correct reporting of retrospective and prospective trials can be found on the editorial office web site.

The first professional organization I joined was EMWA (European Medical Writers Association) [7]. I wanted to see things from the authors' perspective and joined EMWA and the development programme, completing both the foundation 
and advanced certificates. After that, I assisted the publisher with reformatting the guidelines of the journal.

I am also a member of EASE (European Association of Science Editors). They have over the years developed guidelines for authors, which have been translated into multiple languages. The guidelines can be downloaded free of charge on their website and I would recommend their use [8].

I discovered ISMTE (International Society of Managing and Technical Editors) by chance in 2010. I was preparing a presentation for the WOC (World Ophthalmology Congress) in Berlin and during preparation discovered the newly founded society. Since then, I have become heavily involved and have been appointed to the board of directors. They are a society that is there for the editorial office and the staff. They are the link between the editorial office and the publishers and fill a great gap, which has been around for so long. With international meetings three times a year-Asia, Europe, and North America, combined with half-day COPE meetings, this is a truly international society. The annual meetings are a mix of debates, workshops, and presentations. Editors, editorial staff, or publishers would find this to be of interest [9].

Back to the journal-when I started I was based in Cologne. The editors I worked with were in Cologne but when in 2005 I relocated to Glasgow, both Prof. Kirchhof and myself were hoping it would work but had little experience of working so remotely. Well this is the positive to take from the developments; not only did it work successfully, but when Prof. Joussen in Berlin and Prof. Wong took over in HongKong (now in Liverpool), communication was not a problem-e-mails and WhatsApp messaging keeps us all in touch.

In 2015, we held our very first virtual online board meeting, which was chaired successfully by our Executive Editor Sverre Klemp.

Many of the authors I met when I began to work at the clinic in Cologne are now head of departments themselves in various universities and continue to contribute and support the journal as reviewers and authors.

The publisher, SpringerNature, has also developed working with the production and support departments, both based in the Philippines. Due to the good communication between the departments and the editorial office, any issues that arise are dealt with efficiently and quickly.

The newest development is currently with the case report section. Due to the lack of printing space and increase in the submissions of original articles, we are unable to consider case reports for the regular issue of the journal but the editors and publisher have been working to bring about an online-only section of Graefe's Case Reports. This venture is still in development and further details will follow once available.

Last but not least, I would like to thank my editorial team who do a marvelous job in ensuring that the papers are processed as professionally as possible, and to the readers, authors, reviewers, publisher, and editors (past and present). I have certainly enjoyed my first two decades and look forward to the next decade.

\section{References}

1. Hong SC (2015) 3D printable retinal imaging adapter for smartphones could go global. Graefes Arch Clin Exp Ophthalmol 253(10):1831-1833

2. Aslam TM, Parry NRA, Murray IJ, Salleh M, Dal Col C, Mirza N, Czanner G, Tahir HJ (2016) Development and testing of an automated computer tablet-based method for self-testing of high and low contrast near visual acuity in ophthalmic patients. Graefes Arch Clin Exp Ophthalmol. doi:10.1007/s/00417-016-3293-2

3. Epstein D, Kirchhof B (2005) The delicate topic of authorship. Graefes Arch Clin Exp Ophthalmol 243:1-2

4. Epstein D (2011) The delicate topic of authorship-2011 update. Graefes Arch Clin Exp Ophthalmol 249:1437-1438

5. Committee on Publication Ethics (2016) www.publicationethics.org/ resources/flowcharts. Accessed 29 Mar 2016

6. Consort transparent reporting of trials (2016) www.consortstatement.org. Accessed 29 Mar 2016

7. European Medical Writers Association (2016) www.emwa.org. Accessed 29 March 2016

8. European Association of Science Editors (2016) www.ease.org.uk. Accessed 29 March 2016

9. International Society of Managing and Technical Editors (2016) www.ismte.org. Accessed 29 March 2016 